\title{
Cytotoxic Effect of Lactobacillus gasseri Concentrated Filtrate on some Tumor Cell Lines in vitro
}

\author{
Shahlaa M. Salih ${ }^{1}$; Tamara H. Zedan* and Abdulameer M. Ghareeb ${ }^{* *}$ \\ *Department of Biotechnology, College of Science, Al-Nahrain University. \\ ** Institute of Genetic Engineering and Biotechnology for Post Graduate, Baghdad University. \\ ${ }^{1}$ E-mail: shehlaam2006@yahoo.com.
}

\begin{abstract}
This study was designed to investigate the cytotoxic effect of Lactobacillus gasseri concentrated filtrate on tumor cell lines. Lb. gasseri was grown in de Mann, Rogosa and Sharp MRS broth medium and incubated anaerobically at $37^{\circ} \mathrm{C}$ for $24 \mathrm{hrs}$. The culture was centrifuged and the supernatant was taken and sterilized by filtration. One hundred $\mathrm{ml}$ of filtrate was concentrated by oven at $40-45^{\circ} \mathrm{C}$ to three- fold $(12.5 \mathrm{ml})$ and different concentrations $(125,250$, 500 , and 1000) $\mu \mathrm{g} / \mathrm{ml}$ were applied on RD, Hep-2, and AMN-3 tumor cell lines and normal cell line REF and incubated at $37^{\circ} \mathrm{C}$ for $24 \mathrm{hrs}$. Results showed that the growth of RD and HepG2 were significantly inhibited $(\mathrm{p} \leq 0.05)$ at $125 \mu \mathrm{g} / \mathrm{ml}$ of filtrate and the percentage of growth inhibition was $(91.9$ and 86.4$) \%$ respectively. The effect was dose-dependent and accordingly $1000 \mu \mathrm{g} / \mathrm{ml}$ recorded the highest percentage of growth inhibition, which was $27.8 \%$ on AMN-3 cells and $32.1 \%$ on REF cell line.
\end{abstract}

Keywords: Lactobacillus gasseri, Filtrate, Cytotoxic effect.

\section{Introduction}

Lactic acid bacteria (LAB) such as Lactobacillus are important micro-organisms in a healthy human microbiotic environment [1]. LAB is beneficial micro-organisms, which have been associated with several probiotic effects in both humans and animals [2]. Numerous reports have indicated that both LAB and fermented milk exert anticancer effects [3,4]. Data from epidemiological and experimental studies have also indicated that the ingestion of certain LAB strains, or of fermented dairy products, might alleviate the risk of certain type of cancers, and inhibit the growth of tumors [5]. Many strains, including Lb. rhamnosus $G G, L b$. acidophilus, Lb. casei, Bifidus longum, Bifidus infantis, Bifidus adolescentis, and Bifidus breve, suppress experimental colon tumor incidence $[6,7]$.The precise mechanism by which LAB exerts anticancer effects has been previously reported to induce apoptosis [8]. Apoptosis (programmed cell death) is frequently impaired in many human tumors, and is also an important phenomenon in chemotherapyinduced tumor cell death. Therefore, the modulation of apoptosis via the targeting of pro-apoptotic and anti-apoptotic proteins may prove to be an effective technique in the treatment of cancer [9].

\section{Materials and Methods \\ Bacterial isolate}

Lb. gasseri was supplied by Immunology Lab., Department of Biotechnology, College of Science, Al-Nahrain University. This isolate was previously isolated from red peach fruit (Prunus persica).

\section{Cell culture}

Three types of cancer cell lines, liver carcinoma cell line (HepG2), Rhabdomyosarcoma cell line (RD), Mice mammary gland carcinoma cell line (AMN), and normal cell line Rat fibroblast cell line (REF) were kindly obtained from Iraqi Center for Cancer Research and Medical Genetics (ICCRMG) and used in this study. Cells were grown at $37{ }^{\circ} \mathrm{C}$ in humidified atmosphere containing $5 \% \mathrm{CO}_{2}$ in RPMI- 1640 medium supplemented with $10 \%$ fetal calf serum(FCS), Glutamine $(2 \mathrm{Mm})$, penicillin $(100 \mathrm{IU} / \mathrm{ml})$, and streptomycin $(100 \mu \mathrm{g} / \mathrm{ml})$ [10]. 


\section{Preparation of concentrated filtrate of $\boldsymbol{L b}$. gasseri}

Tube containing de Mann, Rogosa and Sharp MRS broth medium was inoculated with $1 \%$ of fresh culture $L b$. gasseri, then incubated anaerobically at $37^{\circ} \mathrm{C}$ for $24 \mathrm{hrs}$. After incubation, culture was centrifuged at $6000 \mathrm{rpm}$ for $15 \mathrm{~min}$., supernatant was taken and sterilized by Ultrafiltration [11]. One hundred $\mathrm{ml}$ of filtrate was concentrated by oven at $40-45^{\circ} \mathrm{C}$ to one fold $(50 \mathrm{ml})$, two -fold $(25 \mathrm{ml})$ and three- fold $(12.5 \mathrm{ml})$. A portion of $100 \mathrm{mg}$ from each of Lactobacillus spp. concentrated filtrate was dissolved in $10 \mathrm{ml}$ of serum free medium, then sterilized by Millipore $0.22 \mu \mathrm{m}$ filter. From these stock solutions, two fold dilutions were made starting from $1000 \mu \mathrm{g} / \mathrm{ml}$ to $125 \mu \mathrm{g} / \mathrm{ml}$.

\section{Cytotoxic assay}

Cytotoxic assay was carried out according to Freshney [10]. Cell suspension was prepared for each type of cell lines and $1 \times 10^{5}$ exponentially growing cells seeded in 96 well tissue culture plates as $(200 \mu \mathrm{L})$ in each well and incubated at $37{ }^{\circ} \mathrm{C}$ for $24 \mathrm{hrs}$. After incubation, the wells were examined for the formation of cell monolayers and $200 \mu \mathrm{l} /$ well from each concentration $(125,250,500$, or $1000) \mu \mathrm{g} / \mathrm{ml}$ of three fold concentrated filtrate were added to the wells as three replicates for each concentration. Three replicates were made for control which contained only the cells growing on growth medium. After $24 \mathrm{hrs,}$ $50 \mu \mathrm{l} /$ well of neutral red dye was added and incubated again for $2 \mathrm{hrs}$. After incubation, the contents of the plate were removed by washing the cells with PBS to remove the excess dye followed by the addition of $20 \mu \mathrm{l} /$ well of extraction dye solution that draw out the dye from the viable cells that had stained. Results were read using ELISA reader at a wave length $492 \mathrm{~nm}$. The percentage of growth inhibition (PGI) was calculated according to the following equation [12].

Growth inhibition $(\%)=\left(\frac{\text { Control Absorbance }- \text { Treated Absorbance }}{\text { Control Absorbance }}\right) \times 100$

\section{Statistical Analysis}

The values of the investigated parameters were given in terms of mean \pm standard error, and differences between means were assessed by analysis of variance (ANOVA), Duncan test, using SPSS computer program version (7.5) was performed Differences in results were considered significant at probability value equals or less than 0.05 [13].

\section{Results}

Results revealed that four concentrations of $L b$ gasseri three fold concentrated filtrate were effective in reducing the growth of RD cell line. The lowest concentration recorded highest percentage of growth inhibition reached $91.9 \%$ compared with control, while, the highest concentration showed the lowest PGI recording 28.9\% (Table (1)).

Table (1)

Growth inhibition effect of Lb gasseri concentrated filtrate on $R D$ cell line after 24 hrs of incubation period.

\begin{tabular}{||c||c||c|}
\hline $\begin{array}{c}\text { Concentration } \\
(\mu \mathrm{g} / \mathrm{ml})\end{array}$ & $\begin{array}{c}\text { O.D. mean } \pm \\
\text { S.E.* }\end{array}$ & $\begin{array}{c}\text { growth } \\
\text { inhibition } \\
(\%)\end{array}$ \\
\hline \hline Control & $0.619 \pm 0.02 \mathrm{a}$ & ---- \\
\hline \hline 125 & $0.050 \pm 0.02 \mathrm{~b}$ & 91.9 \\
\hline 250 & $0.400 \pm 0.032 \mathrm{c}$ & 35.3 \\
\hline \hline 500 & $0.435 \pm 0.02 \mathrm{~d}$ & 29.7 \\
\hline 1000 & $0.440 \pm 0.03 \mathrm{e}$ & 28.9 \\
\hline
\end{tabular}

*different letters $=$ significant differences $(P \leq 0.05)$ between means and control treatment only.

According to the results indicated in Table (2), the first concentration of Lb gasseri, three fold concentrated filtrate displayed a significant cytotoxic effect on HepG2 cell line since PGI for this concentration was $86.4 \%$ compared with control. Other concentrations $(250,500$, and 1000) $\mu \mathrm{g} / \mathrm{ml}$ were not significant PGI $(17.1 \%, 4.0 \%$, and $4.2 \%)$ respectively. 
Table (2)

Growth inhibition effect of Lb gasseri concentrated filtrate on HepG2 cell line after 24 hrs of incubation period.

\begin{tabular}{||c||c||c||}
\hline $\begin{array}{c}\text { Concentration } \\
(\mu \mathrm{g} / \mathrm{ml})\end{array}$ & $\begin{array}{c}\text { O.D. mean } \pm \\
\text { S.E.* }\end{array}$ & $\begin{array}{c}\text { growth } \\
\text { inhibition } \\
(\%)\end{array}$ \\
\hline \hline Control & $0.450 \pm 0.02 \mathrm{a}$ & ---- \\
\hline \hline 125 & $0.061 \pm 0.02 \mathrm{~b}$ & 86.4 \\
\hline 250 & $0.373 \pm 0.02 \mathrm{a}$ & 17.1 \\
\hline 500 & $0.432 \pm 0.02 \mathrm{a}$ & 4 \\
\hline \hline 1000 & $0.431 \pm 0.02 \mathrm{a}$ & 4.2 \\
\hline
\end{tabular}

*different letters $=$ significant differences $(P \leq 0.05)$ between means and control treatment only.

As shown in Table (3), results indicated that only 250,500 and $1000 \mu \mathrm{g} / \mathrm{ml}$ of $L b$ gasseri three fold concentrated filtrate had a significant cytotoxic effect on AMN cell line since PGI for these concentrations were $23.9 \%, 24.0 \%$, and $27.8 \%$ compared with control. The first concentration had no significant cytotoxic effect and PGI for this concentration was $11.4 \%$.

Table (3)

Growth inhibition effect of Lb gasseri concentrated filtrate on AMN cell line after 24 hrs incubation period.

\begin{tabular}{||c||c||c||}
\hline $\begin{array}{c}\text { Concentration } \\
(\mu \mathrm{g} / \mathrm{ml})\end{array}$ & $\begin{array}{c}\text { O.D. mean } \pm \\
\text { S.E.* }\end{array}$ & $\begin{array}{c}\text { growth } \\
\text { inhibition } \\
(\%)\end{array}$ \\
\hline \hline Control & $0.610 \pm 0.02 \mathrm{a}$ & ---- \\
\hline 125 & $0.540 \pm 0.02 \mathrm{a}$ & 11.4 \\
\hline 250 & $0.461 \pm 0.03 \mathrm{~b}$ & 24.4 \\
\hline \hline 500 & $0.463 \pm 0.02 \mathrm{c}$ & 24 \\
\hline \hline 1000 & $0.440 \pm 0.03 \mathrm{~d}$ & 27.8 \\
\hline
\end{tabular}

*different letters $=$ significant differences $(P \leq 0.05)$ between mean and control treatment only.

Table (4) showed that the three fold concentrated filtrate of $L b$. gasseri had significant cytotoxic effect on growth of REF at500 and $1000 \mu \mathrm{g} / \mathrm{ml}$ with PGI of $(35 \%$ and $32.1 \%$ ) respectively when compared with the control. The first and second concentrations exerted significant cytotoxic effect on normal cell line and PGI were $24.2 \%$ and $24.6 \%$ respectively.

Table (4)

Growth inhibition effect of Lb gasseri concentrated filterate on REF cell line after 24 hrs incubation period.

\begin{tabular}{|c|c|c|}
\hline $\begin{array}{c}\text { Concentration } \\
(\mu \mathrm{g} / \mathrm{ml})\end{array}$ & $\begin{array}{l}\text { O.D. mean } \pm \\
\text { S.E.* }\end{array}$ & $\begin{array}{c}\text { growth } \\
\text { inhibition } \\
(\%)\end{array}$ \\
\hline Control & $0.280 \pm 0.02 \mathrm{a}$ & ---- \\
\hline 125 & $0.212 \pm 0.03 \mathrm{~b}$ & 24.2 \\
\hline 250 & $0.211 \pm 0.02 \mathrm{c}$ & 24.6 \\
\hline 500 & $0.182 \pm 0.02 \mathrm{~d}$ & 35 \\
\hline 1000 & $0.190 \pm 0.03 \mathrm{e}$ & 32.1 \\
\hline
\end{tabular}

\section{Discussion}

Results revealed that three fold concentrated filtrate of $L b$. gasseri showed cytotoxic effect on RD, Hep-G2 and AMN-3. This might be due to the secondary metabolites produced by LAB such as hydrogen peroxide $\left(\mathrm{H}_{2} \mathrm{O}_{2}\right)$ which is capable of inducing apoptosis [14]. A similar result was obtained by Huanget al., [15] who reported that direct exposure of human hepatoma cell line (SMMC- 7221) to hydrogen peroxide induces apoptosis characterized by morphological evidence and fragmentation of DNA assayed by terminal deoxynucleotidyl transferase assay and confirmed that $\mathrm{H}_{2} \mathrm{O}_{2}$ can also activate the differential expression of some specific gene such as p53. The p53 tumor suppressor gene is an essential mediator of the mammalian cells and it is required for apoptosis. Subsequently, p53 activates the transcription of several genes whose products are involved in DNA repair or apoptosis. Another study showed that glycoproteins detected in the supernatants of Lactobacillus cultures also have anti-tumor effects [16].

Moreover, this effect could be attributed to polysaccharides produced by LAB [17] as reported by Hyun et.al. [18] who showed that the polysaccharide fraction (BB-pol) extracted from $B$. bifidum BGN4 had a novel composition, comprising from chiroinositol, rhamnose, glucose, galactose, and ribose and inhibited the growth of HT-29 and HCT-116 
cells but did not inhibit the growth of Caco-2 cells.

Kim etal. [19] showed that expression of Bcl-2 interacting protein and cell division cycle protein were significantly regulated by the polysaccharides isolated from $L b$. acidophilus 606 in proteomic analysis.

\section{Conclusion:}

It is concluded from this study that three fold concentrated filterate of $L b$. gasseri showed a cytotoxic effect on the three types of tumor cell lines and normal cell line under investigations.

\section{References}

[1] Macfarlane, G.T. and Cummings, J.H. Probiotics, infection and immunity. Curr Opin Infect Dis., 15, 501-506. (2002).

[2] Fuller, R. Probiotics in man and animal. J Appl Bacteriol66, 365-378. (1989).

[3] Biffi, A.; Coradini, D.; Larsen, R.; Riva, L. and Di Fronzo, G. Antiproliferative effect of fermented milk on the growth of a human breast cancer cell line. Nutr Cancer, 28, 9399. (1997).

[4] Lee, J.W.; Shin, J.G.; Kim, E.H.; Joo, H.G. and Woo, H.J. Immunomodulatory and antitumor effects in vivo by the cytoplasmic fraction of Lactobacillus casei and Bifidobacterium longum. J Vet Sci 5, 4148. (2004).

[5] Kato, I.; Endo, K.; and Yokokura, T. Effects of oral administration of Lactobacillus casei on antitumor responses induced by tumor resection in mice. Int $\mathrm{J}$ Immunopharmacol 16, 29-36. (1994).

[6] Sekine, K.; Ohta, J.; Onishi, M.; and Hashimoto, Y.: Analysis of antitumor properties of effector cells stimulated with a cell wall preparation (WPG) of Bifidobacterium infantis.Biol Pharm Bull, 18:148-153. (1995).

[7] Singh, J.; Rivenson, A.; Tomita, M. and Reddy BS: Bifidobacterium longum, a lactic acid-producing intestinal bacterium inhibits colon cancer and modulates the intermediate biomarkers of coloncarcinogenesis. Cacinogenesis, 18:833-841. (1997).

[8] Di Marzio, L.; Russo, F.P.; D'Alo, S., Biordi, L., and Cifone, M.G.. Apoptotic effects of selected strains of lactic acid bacteria on a human $\mathrm{T}$ leukemia cell line are associated with bacterial arginine deiminase and/ or sphingomyelinase activities. Nutr Cancer 40, 185-196. (2001).

[9] Hu, W. and Kavanagh, J.J.. Anticancer therapy targeting the apoptotic pathway. Lancet Oncol 4, 721-729. (2003).

[10] Freshney, R.. Culture of animal cells. A manual for basic technique. $4^{\text {th }}$ Eedition. Wiley-liss, Ajohuwiley and Sons. Inc. Publication, New York. (2000).

[11] Erdo rul, G. and Erbilir, F.. Isolation and characterization of Lactobacillus bulgaricus and Lactobacillus casei from various foods. Turk. J. Biol., 30: 39-44. (2006).

[12] Phuangsab, A.; Lorence, R.M.; Reichard, K.W.; Peeples, M.E; and Walters, R.J.. Newcastle disease virus therapy of human tumor zenograftsi on antitumor effects of local or systemic administration. Cancer Lett., 172:72-36. (2001).

[13] McCullough, B.D. and Wilson, B.. "On the accuracy of statistical procedures in Microsoft Excel 2003." Computational Statistics and Data Analysis. Vol. 49, 1244-1252. (2005).

[14] Strus, M.; Janczyk, A. ;Gonet-Surowka, A.; and Heczko, PB.. Effect of hydrogen peroxide of bacterial origin on apoptosis and necrosis of gut mucosa epithelial cells as a possible pathomechanism of inflammatory bowel disease and cancer. J. Physiol Pharmacol., 60 6:55-60. (2009).

[15] Huang, C.; Li, J.; Zheng, R. and Cui, K.. Hydrogen peroxideinduced apoptosis in human hepatoma cells is mediated by CD95 (APO- 1/Fas) receptor/ligand system and may involve activation of wild-type p53. Molecul. Biol. Reports, 27:1-11. (2000).

[16] Manjunath, N. and Ranganathan, B. A cytotoxic substance produced by a wild culture of Lactobacillus casei D-34 against tumor cells. Indial J Exp Bio,l 27:141-145. (1989).

[17] Oda, M., H. Hasegawa, S. Komatsu, M. Kambe, and F. Tsuchiya. Anti-tumor polysaccharide from Lactobacillussp. Agric. Biol. Chem. 47:1623-1625. (1983). 
[18] Hyun Ju You, Deok-Kun Oh and Geun Eog Ji. Anticancerogenic effect of a novel chiroinositol-containing polysaccharide from Bifidobacterium bifidum BGN4 FEMS Microbiology Letters 240: 131136. (2004)

[19] Kim, Y.;Oh, S.;Moon, Y.I. and Kim, S.H. Genetics, Metabolism and Applications. In Abstr. 8th Symposium on Lactic Acid Bacteria. http://www.lab8.nl/ (abstract no. H-061).(2005).

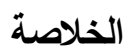

اجريت الدراسة لمعرفة التأثير السي لراشح بكتريا

Lactobacillus gasseri الزجاج. نميت بكتريا Lb. gasseri في وسط MRS السائل

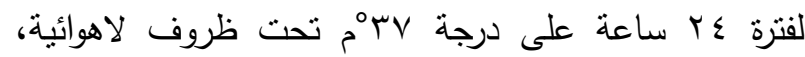

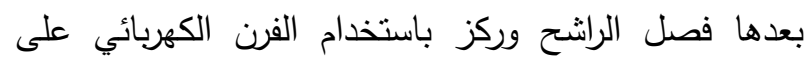

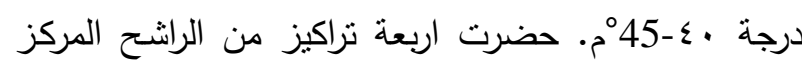

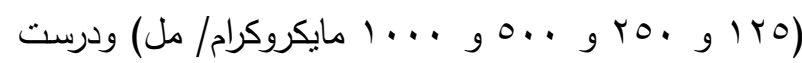

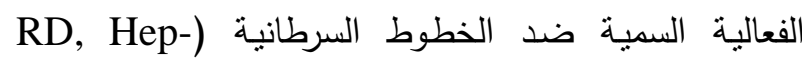

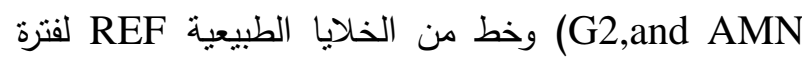
حضانة

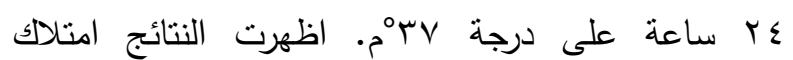
التراكيز الواطئة 125/ml 125 من الراشح المركز فعالية سمية ضد Hep-G2 و RD حيث كانت النسبة المئوية للتثبط 86.4\% و 91.9\% على التوالي، بينما اعطت

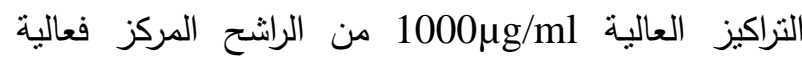
سمية ضد AMN حيث كانت النسبة المئوية للتثبط 27.8\%. اظهرت النتائج ان النسبة المئوية للتثيط ضد الخط

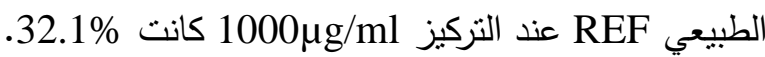

